\title{
Aphid Species Colonizing Conifer, Juniper and Cedar Trees along Hungarian Motorways
}

\author{
ZS. BASKY \\ Plant Protection Institute, Centre for Agricultural Research, Hungarian Academy of Sciences \\ Herman Ottó u. 15, H-1022 Budapest, Hungary
}

(Received: 18 June 2015; accepted: 10 July 2015)

\begin{abstract}
Survey of aphids on dicotyledonous herbaceous plants along the Hungarian highways on 33 sampling points revealed the presence of 14 aphid species on gymnosperm trees. The most frequent conifer species was: Pinus nigra J. F. Arnold 1785 (21 locations) followed by Pinus sylvestris L.1753, Picea abies (L.) H. Karst. (4 locations), Juniperus communis L. 1753 (3 locations) and Juniperus virginiana L. 1753 (1 location), Thuja occidentalis L.1753 (2 locations), Thuja plicata Donn ex D. Don (1 location).

Eulachnus agilis (Kaltenbach, 1843) was the most frequently collected aphid species on Pinus nigra, followed by Cinara brauni Börner, 1940, Cinara schimitscheki Börner, 1940, Eulachnus rileyi (Williams, 1911) and Cinara acutirostris Hille Ris Lambers, 1956. The less frequent Cinara species was Cinara piniphila (Ratzeburg, 1844) which is a new record for the Hungarian fauna. Pinus sylvestris accommodated three aphid species: Cinara intermedia Pašek, 1954 was the most frequent, followed by Cinara pinea (Mordvilko, 1895) and Eulachnus agilis. Picea abies accommodated Cinara piceae, Cinara pruinosa (Hartig, 1841), Cinara piceicola (Cholodkovsky, 1896) and Sacchiphantes abietis L. 1758. Juniperus communis and J. virginiana most frequently hosted Cinara juniperi (De Geer, 1773). Eulachnus agilis occurred once on Juniperus communis. A single aphid species Cinara tujafilina was found on Thuja occidentalis and Thuja plicata.
\end{abstract}

Keywords: Cinara, Eulachnus, aphid species, Pinus nigra, Picea, Juniperus, Thuja, host species, Hungary.

Construction of motorways starts with mapping out the route. Mark the line out for the motorway on the location. Elimination of difference of level and road bed construction require leveling of the ground. During this procedure the natural vegetation is destroyed.

In the final stage of the construction vegetation cover has to be established along roadsides. Although it is not a technical process; it is the duty of the executor. Above all the executor is responsible for the stage of the vegetation cover for 2-3 years after the construction has been finished (Forman et al., 2003).

Therefore plant species with high stress toleration ability has been chosen for establishing vegetation cover. These plants have a wide genetic tolerance to environmental conditions, such as moist to dry or cool to hot (Forman et al., 2003).

From the tree species the black pine Pinus nigra J. F. Arnold 1785 is one of the best examples of high ecological plasticity. It can be found at elevations ranging from sea level to 2000 meters, most commonly from 250-1600 meters. It is native to the Mediterranean

\footnotetext{
*E-mail: basky.zsuzsa@agrar.mta.hu
} 
forests of southern Italy, Sicily and Turkey. There are remnant populations in the higher Atlas Mountains in Morocco and Algeria (Farjon, 2011).

Scots pine, Pinus sylvestris L. 1753 is a species of pine that is native to Europe and Asia, ranging from western Siberia south to Caucasus Mountains Anatolia, and north to well inside the Arctic Circle in Scandinavia. In the north of its range, it occurs from sea level to $1000 \mathrm{~m}$, while in the south of its range it is a high altitude mountain tree, growing at 1200-2600 meters altitude (Kinloch et al., 1986).

Norway spruce Picea abies (L.) H. Karst. is native to Central and Eastern Europe. It grows throughout Europe from Norway in the northwest and Poland eastward, and also in the mountains of central Europe, southwest to the western end of the Alps, and southeast in the Carpathians and Balkans to extreme north of Greece. The northern limit is in the arctic, just north of $70^{\circ} \mathrm{N}$ in Norway. Its eastern limit in Russia is hard to define, due to extensive hybridization with the Siberian spruce, but is usually given as the Ural Mountains (Løkke, 1990).

Common juniper Juniperus communis L. 1753 is native to the UK and much of the northern hemisphere. It thrives on chalk down land, moor land, in rocky areas. It is the major flora element of the chalky sandy soil in Bugac puszta, Hungary (Adams et al., 2003).

The red cedar or eastern red cedar Juniperus virginiana L. 1753 is native to eastern North America from southern Canada to the Gulf of Mexico and east of the Great Plains 3. It is a pioneer invader, which means that is one of the first trees to repopulate cleared, eroded, or otherwise damaged land. The tree is commonly found in prairies, old pastures, or limestone hills, often along highways and near recent construction sites (McKinley et al., 2008).

Western or Pacific red cedar Thuja occidentalis L.1753 is native to Manitoba east throughout the Great Lakes region and into Québec, Vermont, New Hampshire, Maine, Prince Edward Island, New Brunswick, and Nova Scotia. Isolated populations exist to the south in Massachusetts, Connecticut, Ohio, Kentucky, Tennessee, North Carolina, Pennsylvania, Maryland, Virginia (Ahlgren, 1957).

Western redcedar Thuja plicata Donn ex D. Don also called Pacific redcedar, giant-cedar, is the only Thuja species native to western North America. Western redcedar grows along the Pacific coast from Alaska to California and inland from the Pacific Ocean to Montana (Chase, 2008).

Cinara species are monoecious and holocyclic: they spend their complete life-cycle on a single plant species, the sexual and asexual phase alternates in their life cycles.

Oviparae and males occur in October, after copulation the female lays its fertile overwintering eggs. Nymphs hatch in spring developing apterae, they produce progenies parthenogenetically. The reproduction of subsequent generations is parthenogenetic during summer (Szelegiewicz, 1977). The Cinara genera is very rich in species, there are about 223 species in the world. Majority of them live in Holarctic region. They are monoecious on coniferous trees, feeding on the bark of young shoots, older twigs with or without needles, branches, trunks or roots (Heie, 1995).

Eulachnus species are monoecious and holocyclic, they live on Pinus nigra, Pinus sylvestris.

Eulachnus agilis does not form large colonies, individuals rather scattered. It colonizes the new and previous year's needles, but has a marked tendency to select senescent 
needles, and it shows an active preference for needles occupied by colonies of Schizolachnus pineti (Heie, 1995).

Sacchiphantes abietis is monoecious and anholocyclic. Alata females occur in October and lay unfertile eggs on the buds. The nymphs hatch in autumn and overwinter at the base of the buds. The nymphs develop wax covered apterae by spring. The apterae lay numerous unfertile eggs at the base of the buds (100-180). The hatching nymphs start to feed under scale of bud. Their feeding causes the development of cone shaped galls. Nymphs enter into the gall. Galls become 1.5-3 cm long pine apple shaped. In August galls dry and chambers open. The nymphs leave the galls and by October they develop into alate (Redfern, 2011; Sopow and Quiring, 2001).

\section{Materials and Methods}

Along the $2655.9 \mathrm{~km}$ long highway network 33 evenly distributed sampling places were marked on rest areas or petrol stations. Aphids were surveyed on host plants from middle of May till the beginning of July in 2011 and 2012. The sampling places are published in Kiss et al. (2013). Branch beating was used for arboreal insect collection from tree species. Five individuals from each tree species were sampled at each location. Beating sheet was placed under branches and branches were beaten three times in the same manner. Arboreal insects were collected from each tree based on 15 beating around the trees. The collected insects were kept in deep freezer until sorting. Sorted aphid individuals were placed into Eppendorf tubes containing $70 \%$ ethanol. Location, sampling date and host plant name were recorded on the labels placed into the tubes. Apart from branch beating aphids were collected from the host plants with fine camel hair brush and similarly treated as aphids collected from branch beating material. Apterous individuals were slide mounted using the method of Szalay-Marzsó (1969). The last step of slide mounting was to dye the cleared individuals according to Kosztarab and Kozár (1978).

Aphids were identified based on the identification keys of Blackman and Eastop (1994), Szelegiewicz (1977) and Heie (1995). The original drawings of Henrik Szelegiewicz published in Szelegiewicz (1977) are included in Figs. 1-13.

\section{Results and Discussion}

The black pine Pinus nigra was the most frequent tree species; it was present on 21 locations from the examined 33 rest areas or petrol stations. $61 \%$ of the collected aphid individuals belonged to the genus Cinara. The remaining $41 \%$ belonged to Eulachnus species (Table 1). On black pine Cinara brauni Börner, 1940 was the most frequent species, it was collected on 13 locations (22.0\%) (Fig. 1), followed by Cinara schimitscheki Börner 1940, 9 locations (15.2\%) (Fig. 2). Cinara acutirostris Hille Ris Lambers, 1956 was found in 6 locations (10.1\%) (Fig. 3); it is a Mediterranean species, together with its host plant it came to Western and central Europe (Szelegiewicz, 1977). A new record for 


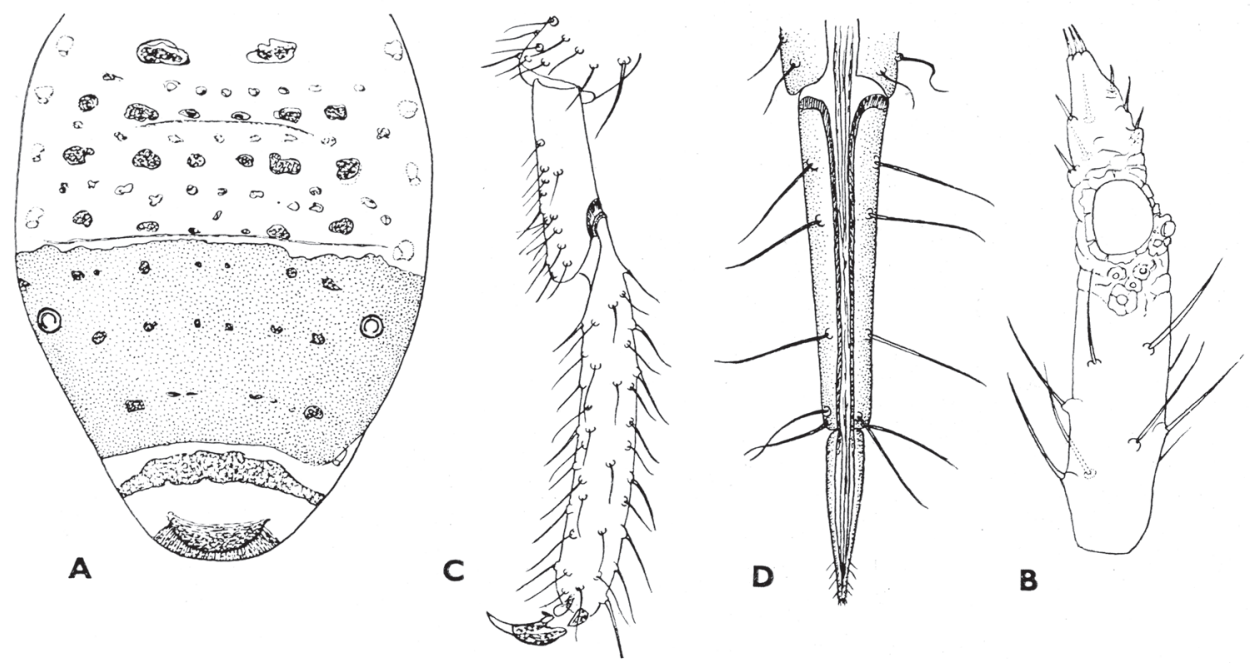

Fig. 1. A: Dorsal abdomen of aptera Cinara brauni Börner, B: flagellum of antennae, C: first hind tarsal segment, D: ultimate rostral segment (RIV+V). Szelegiewicz (1977)

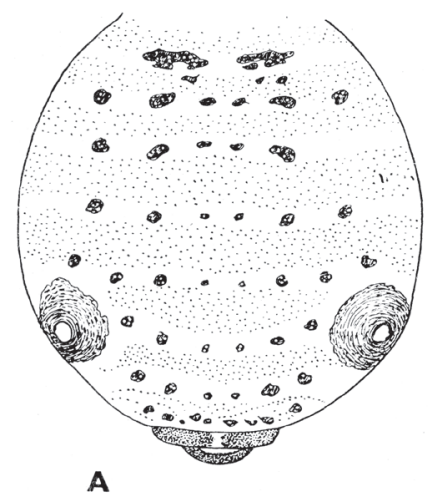

A
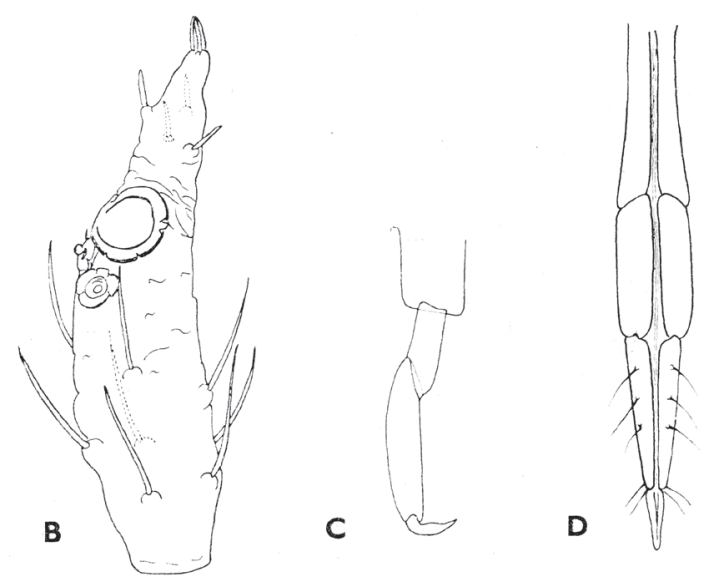

C

Fig. 2. A: Dorsal abdomen of aptera Cinara schimitscheki Börner, B: flagellum of antennae,

C: first hind tarsal segment, D: ultimate rostral segment (RIV+V). Szelegiewicz (1977) 


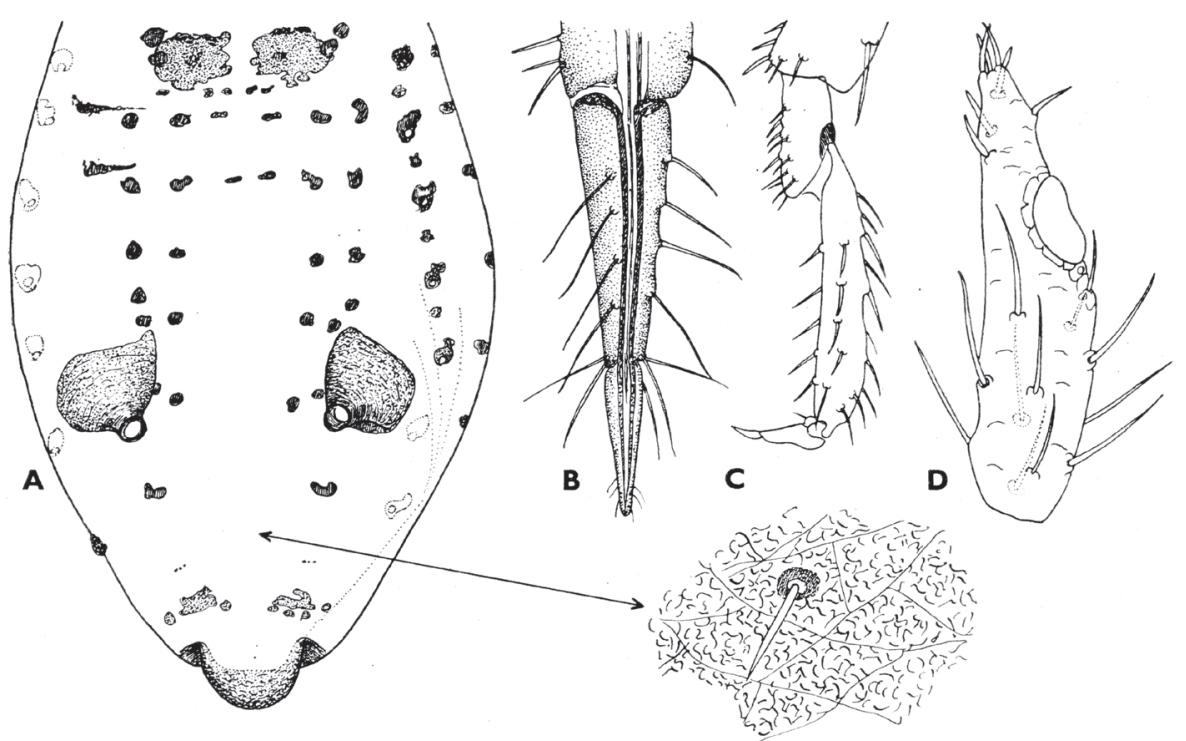

Fig. 3. A: Dorsal abdomen of aptera Cinara acutirostris Hille Ris Lambers, magnification of back sculpture, B: flagellum of antennae, C: first hind tarsal segment, D: Ultimate rostral segment (RIV+V). Szelegiewicz (1977)

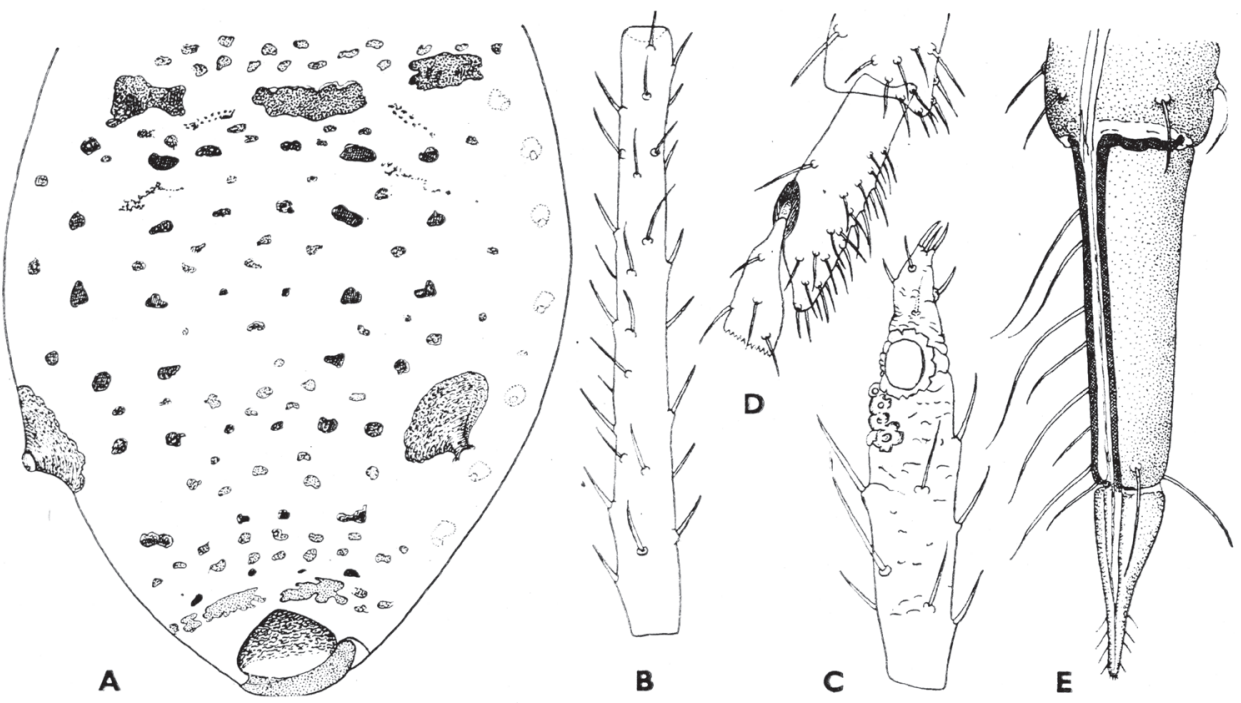

Fig. 4. A: Dorsal abdomen of aptera Cinara piniphila Ratzeburg, B: third antennal segment, C: flagellum of antennae, D: first hind tarsal segment,

E: ultimate rostral segment (RIV+V). Szelegiewicz (1977) 

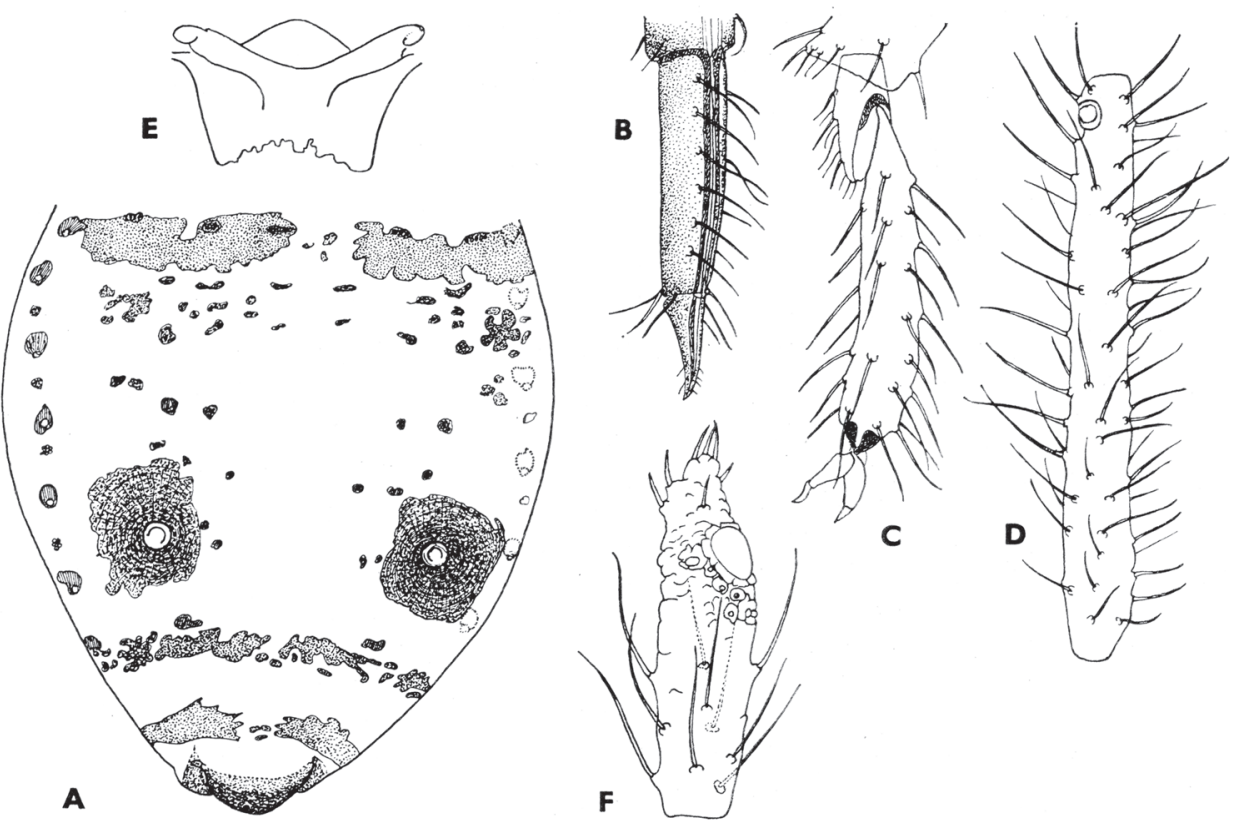

Fig. 5. A: Dorsal abdomen of aptera Cinara intermedia Pašek, B: ultimate rostral segment (RIV+V), C: first hind tarsal segment, D: third antennal segment, E: mesosternum, F: flagellum of antennae. Szelegiewicz (1977)

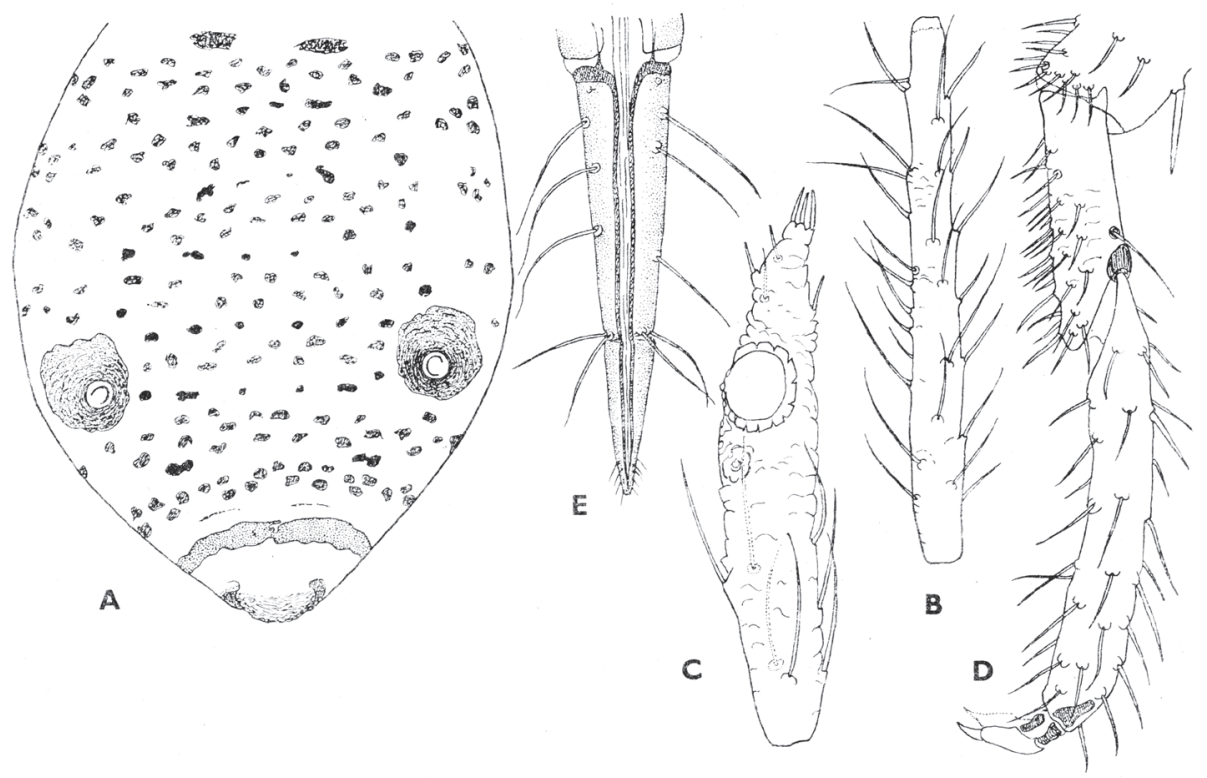

Fig. 6. A: Dorsal abdomen of aptera Cinara pinea Mordvilko, B: third antennal segment, C: flagellum of antennae, D: first hind tarsal segment, E: ultimate rostral segment (RIV+V). Szelegiewicz (1977) 

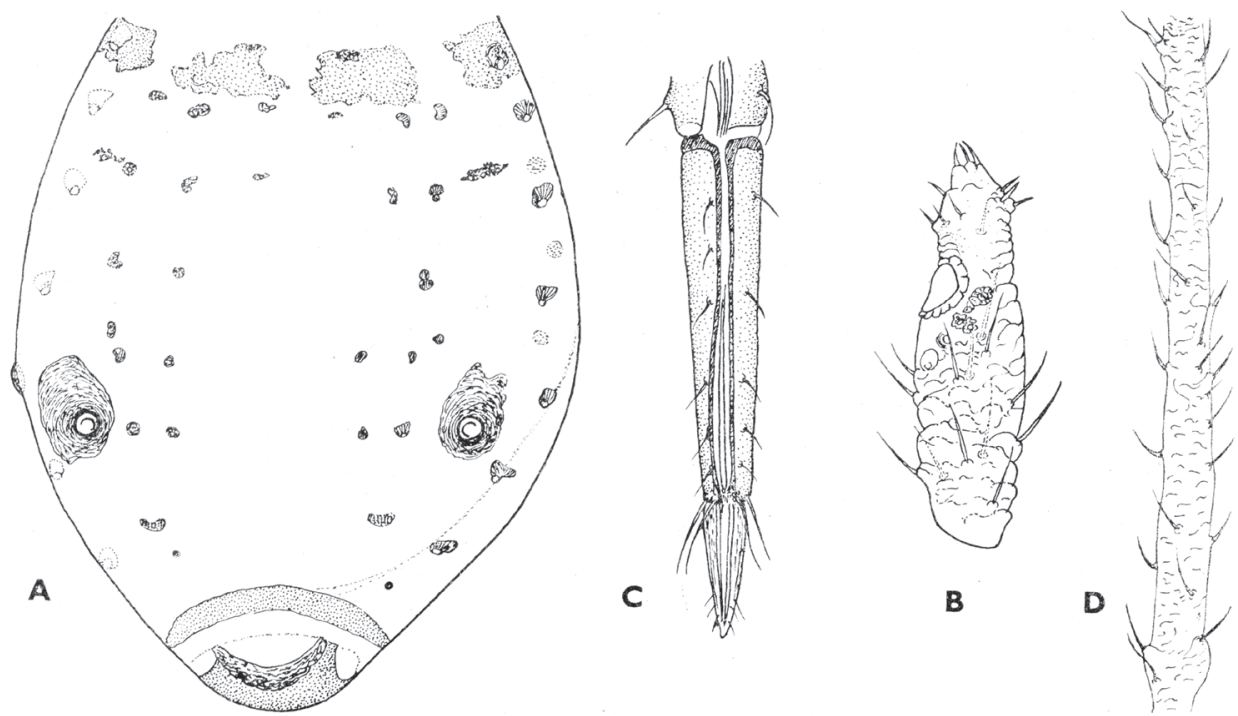

Fig. 7. A: Dorsal abdomen of aptera Cinara picea Panzer, B: flagellum of antennae, C: ultimate rostral segment (RIV+V), D: third antennal segment. Szelegiewicz (1977)

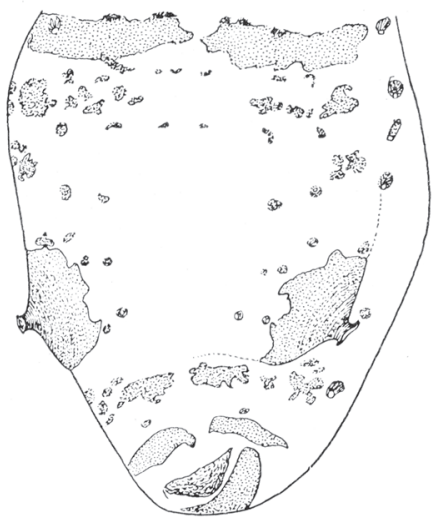

A

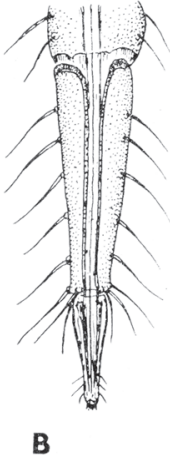

B

Fig. 8. A: Dorsal abdomen of aptera Cinara pruinosa Hartig, B: ultimate rostral segment (RIV+V), C: first hind tarsal segment, D: flagellum of antennae. Szelegiewicz (1977) 


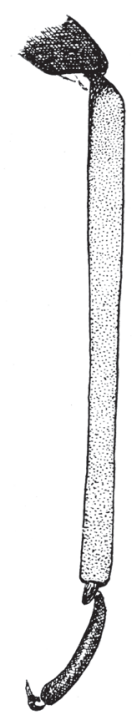

A
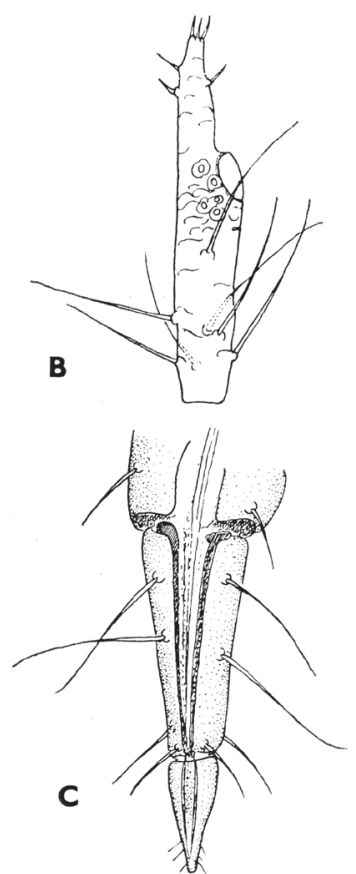

Fig. 9. A: Hind tibia of aptera Cinara juniperi De Geer, B: flagellum of antennae, C: ultimate rostral segment (RIV+V). Szelegiewicz (1977)

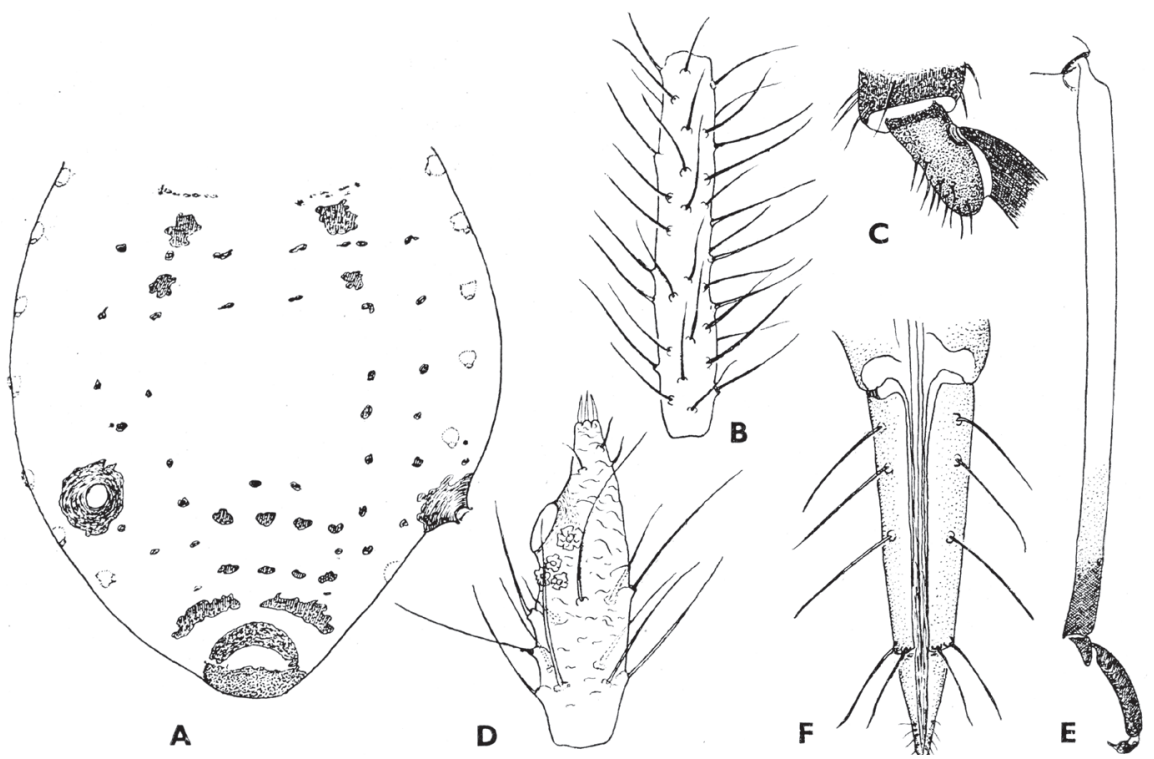

Fig. 10. A: Dorsal abdomen of aptera Cinara tujafilina Del Guercio, B: third antennal segment, C: first hind tarsal segment, D: flagellum of antennae, E: hind tibia of aptera, F: ultimate rostral segment (RIV+V). Szelegiewicz (1977) 

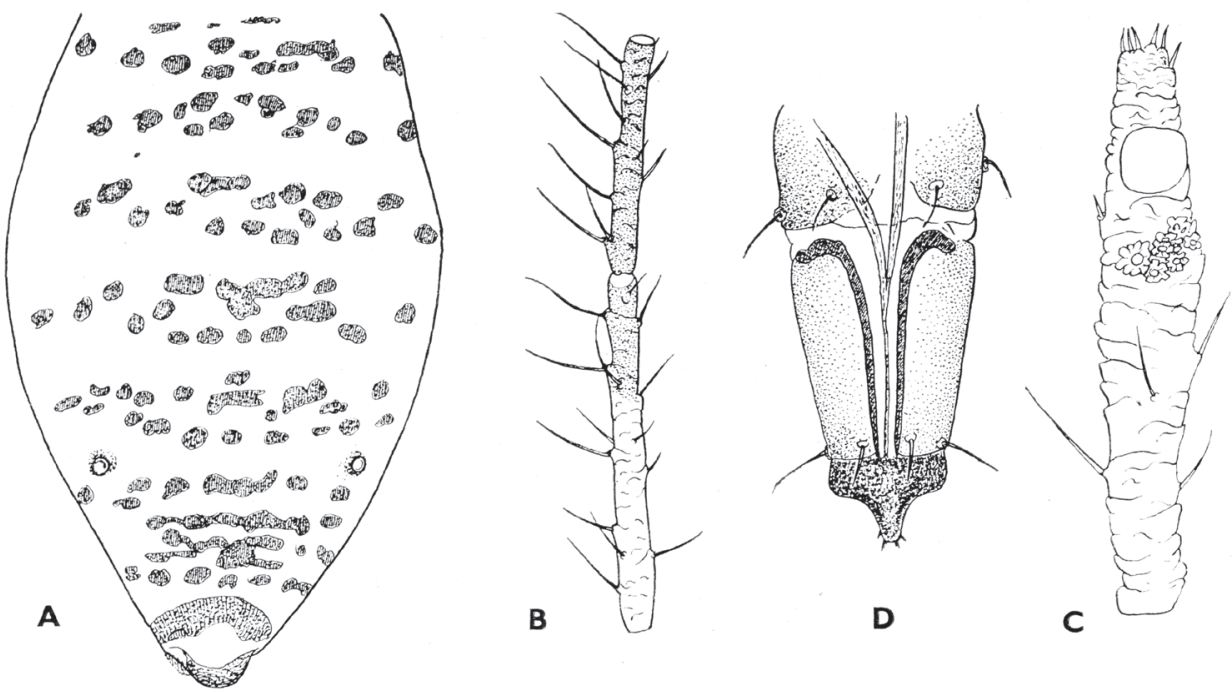

Fig. 11. A: Dorsal abdomen of aptera Eulachnus agilis Kaltenbach, B: third and fourth antennal segments, C: flagellum of antennae D: ultimate rostral segment (RIV+V). Szelegiewicz (1977)
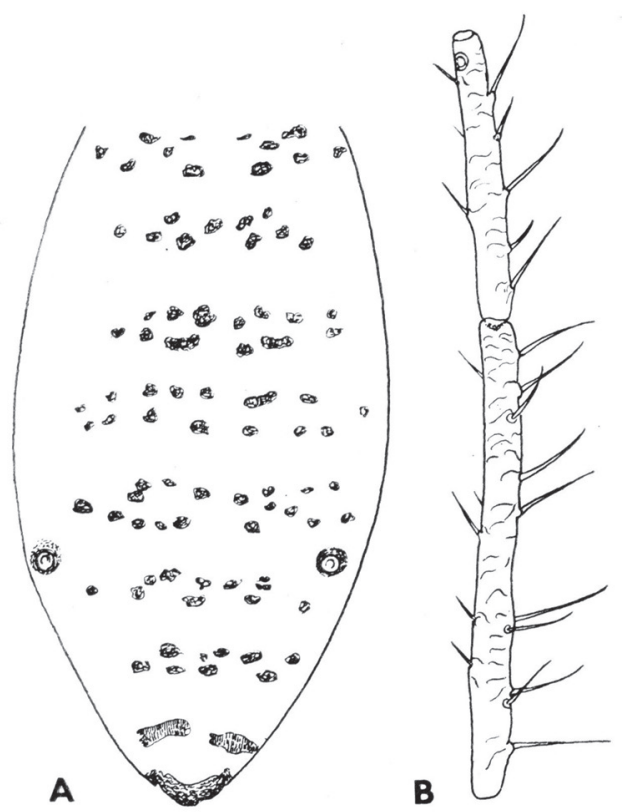

Fig. 12. A: Dorsal abdomen of aptera Eulachnus rileyi Williams, B: third and fourth antennal segments 


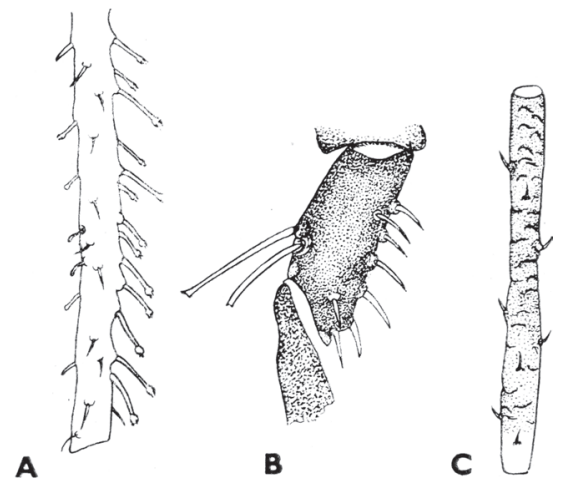

Fig. 13. A: Hind tibia of Eulachnus nigricola Pašek, B: First segment of hind tarsus, C: third antennal segment

the Hungarian aphid fauna is Cinara piniphila (Ratzeburg, 1844) (Fig. 4); it occurred in 2 locations (Table 1).

Scots pine, Pinus sylvestris was present in 4 locations. Cinara intermedia Pašek, 1954 was present in all locations on Scots pine (Fig. 5), Cinara pinea (Mordvilko, 1895) (Fig. 6) was collected from 3 locations.

Norway spruce, Picea abies accommodated 4 aphid species. Cinara piceae (Panzer, 1801) (Fig. 7) occurred at each location, however, Cinara pruinosa (Hartig, 1841) (Fig. 8), Cinara piceicola (Cholodkovsky, 1896) and Sacchiphantes abietis L. 1758 were collected only once.

Cinara juniperi (De Geer, 1773) (Fig. 9) was present both on common juniper, Juniperus communis L. 1753. and Juniperus virginiana L. 1753. Cinara tujafilina (Del Guercio, 1909) (Fig. 10) was collected from Thuja species.

On Pinus nigra, from the Eulachnus species Eulachnus agilis (Kaltenbach, 1843) (Fig. 11) was the most frequently collected species; it occurred on 14 locations $(23.7 \%)$ on the black pine. The next in the frequency order is Eulachnus rileyi (Williams, 1911) (Fig. 12), which was collected in 8 locations (13.6\%). Eulachnus nigricola Pašek, 1953 (Fig. 13) occurred on Pinus nigra in one location (Table 1). On Scots pine, Eulachnus agilis occurred in 2 locations (Table 1).

The black or Corsican pine was the most frequently found tree species on the selected sampling places, all together 63 samples were collected from $P$. nigra. The Corsican pineshoot aphid (Cinara brauni) and C. schimitscheki were the most frequent Cinara species, followed by Corsican pine aphid $C$. acutirostris and $C$. piniphila on $P$. nigra. The individuals listed as Cinara sp. were nymphs collected early spring, therefore could not be identified into species. The new record for the Hungarian aphid fauna is Cinara piniphila. This species was found in 2 locations and it was found in 2 subsequent years in one of the locations.

The spotted green pine needle aphid (Eulachnus agilis) was the most frequently collected Eulachnus species on Corsican pine, followed by the active grey pine needle aphid (Eulachnus rileyi). 
Table 1

Frequency of aphid species occurring on conifer species along the higway margins in Hungary 2011-2013

\begin{tabular}{llllc}
\hline \multicolumn{1}{c}{ Aphid species } & \multicolumn{1}{c}{ Auctor } & \multicolumn{1}{c}{ Host plant species } & \multicolumn{1}{c}{ Auctor } & Frequency \\
\hline Cinara acutirostris & Hille Ris Lambers, 1956 & Pinus nigra & Arnold & 6 \\
Cinara brauni & Börner, 1940 & Pinus nigra & Arnold & 13 \\
Cinara schimitscheki & Börner, 1940 & Pinus nigra & Arnold & 9 \\
Cinara piniphila & (Ratzeburg, 1844) & Pinus nigra & Arnold & 3 \\
Cinara sp. & & Pinus nigra & Arnold & 5 \\
Eulachnus agilis & (Kaltenbach, 1843) & Pinus nigra & Arnold & 14 \\
Eulachnus rileyi & (Williams, 1911) & Pinus nigra & Arnold & 8 \\
Eulachnus nigricola & Pašek, 1953 & Pinus nigra & Arnold & 1 \\
Cinara intermedia & Pašek, 1954 & Pinus sylvestris & L. & 5 \\
Cinara pinea & (Mordvilko, 1895) & Pinus sylvestris & L. & 3 \\
Eulachnus agilis & (Kaltenbach, 1843) & Pinus sylvestris & L. & 2 \\
Cinara piceae & (Panzer, 1801) & Picea abies & (L.) H. Karst & 4 \\
Cinara pruinosa & (Hartig, 1841) & Picea abies & (L.) H. Karst & 1 \\
Cinara piceicola & (Cholodkovsky, 1896) & Picea abies & (L.) H. Karst & 1 \\
Sacchiphantes abietis & Linnaeus, 1758 & Picea abies & (L.) H. Karst & 1 \\
Cinara juniperi & (De Geer, 1773) & Juniperus communis & L. & 4 \\
Eulachnus agilis & (Kaltenbach, 1843) & Juniperus communis & L. & 1 \\
Cinara juniperi & (De Geer, 1773) & Juniperus virginiana & L. & 4 \\
Cinara tujafilina & (Del Guercio, 1909) & Thuja occidentalis & L. & 3 \\
\hline Cinara tujafilina & (Del Guercio, 1909) & Thuja plicata & Donn ex D. Don & 1 \\
\hline
\end{tabular}

The number of samples collected from the five other pine species was less than half of that of collected from black pine. However, Cinara species specialized for certain tree species were the following: Scots pine (P. sylvestris) Cinara intermedia and C. pinea, Norway spruce, $P$. abies accommodated: C. piceae, C. pruinosa, C. piceicola and Sacchiphantes abietis. Cinara juniperi was present on Juniperus species and Cinara tujafilina on Thuja species.

\section{Acknowledgements}

The author wishes to thank for the financial support of OTKA project number 83829. Grateful thanks are due to Dr G. Ripka for his valuable advices during manuscript preparation, Ágnes Valiskó Hornyák for mounting the slides. Special thanks are due to Dr Éva Szita for digitalization of the original drawings from the book of Szelegiewicz (1977). 


\section{Literature}

Adams, R. P., Pandey, R. N., Leverenz, J. W., Dignard, N., Hoegh, K. and Thorfinnsson, T. (2003): Pan-Arctic variation in Juniperus communis: Historical Biogeography based on DNA fingerprinting. Biochemical Systematics and Ecology 31, 181-192.

Ahlgren, C. E. (1957): Phenological observations of nineteen native tree species in northeastern Minnesota. Ecology 38, 622-628.

Blackman, R. L. and Eastop, V. F. (1994): Aphids on the World's Trees an Identification and Information Guide. CAB International, Wallingford Oxon UK, 987 pp.

Chase, J. (2008): "Western Redcedar", "Tree of Life" (PDF). Forests for Oregon. Oregon Department of Forestry, pp. 18-24.

Farjon, A. (2011): Pinus nigra. 2006. IUCN Red List of Threatened Species. IUCN 2006. www.iucnredlist.org. Retrieved on 15 February 2015.

Forman, R. T. T., Sperling, D., Bissonette, J. A., Clevenger, A. P., Cutshall, C. D., Dale, V. H., Fahrig, L., France, R., Goldman, C. R., Heanue, K., Jones, J. A., Swanson, F. J., Turrentine, T. and Winter, T. C. (2003): Road Ecology. Science and Solutions. Island Press, Washington, Covelo, London, 481 p.

Heie, O. E. (1995): The Aphidoidea (Hemiptera) of Fennoscandia and Denmark, VI. Fauna Entomologica Scandinavica. E. J. Brill Leiden, New York, Köln, Vol. 31, 222 p.

Kinloch, B. B., Westfall, R. D. and Forrest, G. I. (1986): Caledonian Scots pine: Origins and genetic structure. New Phytologist 104, 703-729.

Kiss, B., Lengyel, G., Nagy, Z. and Kárpáti, Z. (2013): First record of spotted wing Drosophila [Drosophila suzuki (Matsumura, 1931)] in Hungary. Növényvédelem, 49, 97-99.

Kosztarab, M. and Kozár, F. (1978): Scale insects - Coccoidea. Fauna Hungariae. Akadémiai Kiadó, Budapest, $192 \mathrm{p}$.

Løkke, H. (1990): Picein and piceol concentrations in Norway spruce. Ecotoxicology and environmental safety 19, 301-309. doi:10.1016/0147-6513(90)90032-Z. PMID 2364913.

McKinley, D. C. and Blair, J. M. (2008): Woody plant encroachment by Juniperus virginiana in a mesic native grassland promotes rapid carbon and nitrogen accrual. Ecosystems 11, 454-468.

Redfern, M. (2011): Big buds, cigars, pineapples and rosettes. In: M. Redfern (ed.): Plant Galls. Collins, London, pp. 1-564.

Sopow, S. L. and Quiring, D. T. (2001): Is gall size a good indicator of adelgid fitness? Entomologia Experimentalis et Apllicata 99, 267-271.

Szalay-Marzsó, L. (1969): Aphids in horticulture. Mezőgazdasági Kiadó, Budapest, pp. 1-186. (in Hungarian)

Szelegiewicz, H. (1977): Levéltetvek I. - Aphidinea - I. Magyarország Állatvilága. Fauna Hungariae XVII. Heteroptera, Homoptera 18. Fauna Hung. 128. Akadémiai Kiadó, Budapest, 175 p. 